\title{
FACTORS AFFECTING AND DETERMINING LOCAL DEPOPULATION
}

\section{Faktori, kas ietekmē un nosaka iedz̄̄votāju skaita lokālo pieaugumu un samazinājumu}

\author{
Eduards Zarins, Juris Paiders \\ University of Latvia, Faculty of Geography and Earth Sciences \\ jpaiders@inbox.lv
}

\begin{abstract}
This paper analyses the factors that influence and determine the local population growth and decrease in rural areas of Latvia based on population changes at micro level (1x1 km square grid areas) in 2000-2018. Quantitative analysis of the spatial structure of the population was carried out in three reference territories. Results suggest that the proportion of territories with population increase in Latvian municipalities (2000-2018) has a very strong and statistically significant correlation to population changes (2000-2018) in the respective municipality. This may lead to the conclusion that the influence of other factors on the location of the territories in the spatial structure of the municipality where population growth is observed is not statistically significant.
\end{abstract}

Keywords: population geography, population changes, spatial population structure

DOI: $10.22364 / \mathrm{fg} .18 .2$

\section{Introduction}

Population shrinkage is a significant problem for Latvia. The main cause of population decrease in Latvia is migration. Migration and its influencing factors are an important area of research in population geography (Bērziņš et al. 2018). The territorial disparities of migration have received the attention of many researchers in Latvia (e.g. Krisjane et al. 2017; Zhitin et al. 2018; Arbidane \& Markevica 2016; Göler et al. 2014; Apsite et al. 2012; Krisjane \& Berzins 2012) and in the European context (Poot et al. 2008; Hazans 2003; Champion 2008). Migration is influenced by the income gap between economically developed and less developed regions (Harris \& Todaro 1970; Greenwood \& Hunt 2003; Boyle et al. 1998), agricultural production efficiency and development (Camaioni et al. 2019; Clark et al. 1997; Chomy et al. 2011; Brodzinski 2007), sustainable forestry and rural area development (Yilmaz et al. 2010; Smallbone 2009) and economic benefit for individuals (Sjaastad 1962).

For example, by researching the key factors affecting rural development in Turkey, 12 key factors affecting village development were identified: geographical location, village size, land productivity, land use, active population, poplar production areas, proximity to a river, housing comfort, drinking water characteristics, fertility of the land, cooperation and investment in social infrastructure (Oddershede et al. 2007). The process of studying rural development must use both objective and subjective data, including the views of local leaders (Straka \& Tuzova 2016). 
Latvia is a country with a high proportion of rural areas: Vidzeme, Latgale and Zemgale are considered rural regions, Kurzeme a transition region, and Pieriga an urban region (Zobena \& Ijabs 2015). Latvia is characterised not only by negative longterm net migration, but also by low birth rates and increased life expectancy (Eglīte et al. 2003; Zvidriņš 2006). Internal migration rates in Latvia change from year to year, but on average they reach $2 \%$ of the total population of the country (Bērziņš 2011). Tourism and agricultural processing, as well as business services (Vēveris et al. 2007) and ecosystem services (Ozolinšs et al. 2015), are becoming important drivers of the economic development of rural areas.

The aim of the study was to identify the factors that influence and determine local population change in rural areas of Latvia.

\section{Data and methods}

The data of the Central Statistical Bureau of Latvia (CSB) on population changes were used in the course of the work. For detailed map comparisons, 6th cycle orthophoto maps, topographic maps, soil maps and CSB maps were used. For the analysis of the spatial structure of the population of the municipalities, a square grid which divides Latvia into $1 \times 1 \mathrm{~km}$ squares was used. For each municipality included in the study, only those squares which are mostly within the territory of the municipality were counted.

Cartographic software (ESRI ArcGIS) was used to visualise the results of the work and to prepare the images.

\section{Results}

According to the results obtained during the research, no statistically significant set of parameters (soil type or fertility, distance to a road, distance to the nearest city, etc.) was identified in relation to population changes at the micro level (1x1 km square grid areas). Observations in several regions (Skriveri, Ozolnieki, Jelgava, Olaine, etc.) did not reveal any identifiable correlations that would allow for generalising about the causes of small population changes in settlements.

In the further course of the work, quantitative analysis of the spatial structure of the population was carried out in three reference territories. Dagda, Aglona and Kraslava municipalities (Figure 1) were selected as territories with significant population decline in 2000-2018. Aizkraukle and Skriveri municipalities were selected as areas with average population decline and Kekava, Salaspils and Stopini municipalities were selected as areas with population increase. 


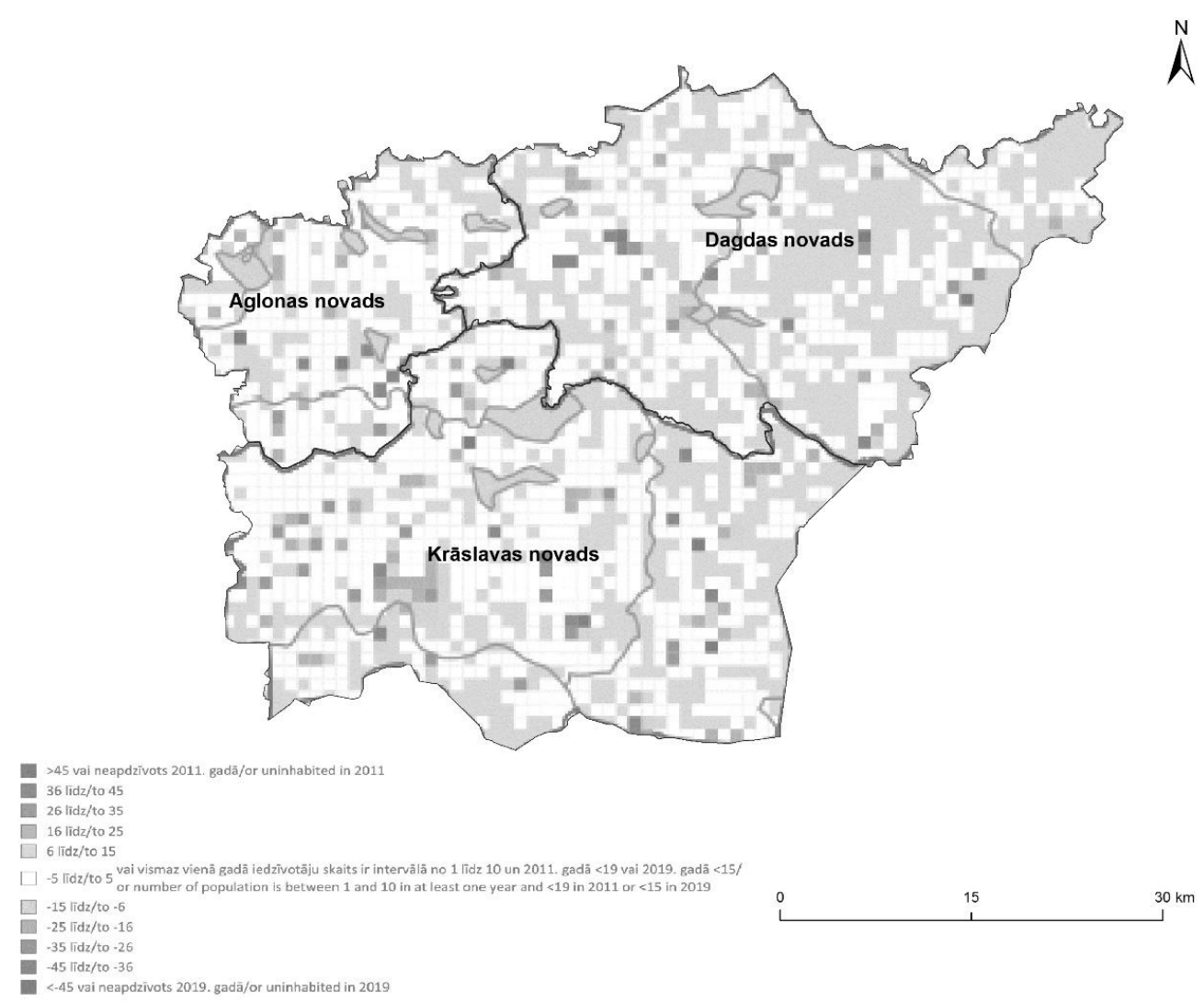

Figure 1. Population changes in 1x1 km square grid areas between 2000 and 2018 in Dagda, Aglona and Kraslava municipalities (authors' figure based on CSB data)

In Dagda, Aglona and Kraslava municipalities (Figure 1), approximately 30 to $50 \%$ of the surveyed area is uninhabited (forests, swamps, etc.). Only about one-tenth of the area experienced population decline. This happened mainly in areas with high population density.

Comparing the changes in the spatial structure of the population in municipalities with a significant decrease in the population, the following results were obtained: between 2000 and 2018 the population of Dagda municipality decreased by $40.4 \%$, and the population increased only in $1.4 \%$ of the populated area; in Aglona municipality these rates are $-37.4 \%$ and $1.6 \%$ respectively; and in Kraslava municipality $-35.5 \%$ and $2.0 \%$ respectively (Table 1 ).

Table 1. Population changes between 2000 and 2018 and changes in the spatial structure of the population in 1x1 km square grid areas between 2000 and 2018 in Dagda, Aglona and Kraslava municipalities (based on CSB data)

\begin{tabular}{|l|c|c|c|}
\hline \multicolumn{1}{|c|}{ Statistical characteristic } & $\begin{array}{c}\text { Aglona } \\
\text { municipality }\end{array}$ & $\begin{array}{c}\text { Dagda } \\
\text { municipality }\end{array}$ & $\begin{array}{c}\text { Kraslava } \\
\text { municipality }\end{array}$ \\
\hline Population at the beginning of 2000 & 5549 & 11178 & 22900 \\
\hline Population at the beginning of 2018 & 3309 & 6992 & 14542 \\
\hline Population changes 2018/2000 (\%) & -40.37 & -37.45 & -36.50 \\
\hline Number of spatial squares & 386 & 953 & 1101 \\
\hline
\end{tabular}




\begin{tabular}{|l|c|c|c|}
\hline \multicolumn{1}{|c|}{ Statistical characteristic } & $\begin{array}{c}\text { Aglona } \\
\text { municipality }\end{array}$ & $\begin{array}{c}\text { Dagda } \\
\text { municipality }\end{array}$ & $\begin{array}{c}\text { Kraslava } \\
\text { municipality }\end{array}$ \\
\hline $\begin{array}{l}\text { Number of spatial squares without } \\
\text { population }\end{array}$ & 99 & 452 & 351 \\
\hline $\begin{array}{l}\text { Number of spatial squares with } \\
\text { population }\end{array}$ & 287 & 501 & 750 \\
\hline $\begin{array}{l}\text { The number of spatial squares in } \\
\text { which the population increased }\end{array}$ & 4 & 8 & 15 \\
\hline $\begin{array}{l}\text { The number of spatial squares in } \\
\text { which the population decreased }\end{array}$ & 33 & 67 & 97 \\
\hline $\begin{array}{l}\text { The percentage of populated spatial } \\
\text { squares in which the population } \\
\text { increased }\end{array}$ & 1.39 & 1.60 & 2.00 \\
\hline $\begin{array}{l}\text { The percentage of populated spatial } \\
\text { squares in which the population } \\
\text { decreased }\end{array}$ & 11.50 & 13.37 & 12.93 \\
\hline
\end{tabular}

In Aizkraukle and Skriveri municipalities, 30-50\% of the study area is uninhabited (forests, swamps, etc.), but in about a quarter of the area the population has decreased. This happened mainly in areas with high population density. In about one-tenth of the area the population increased.

Comparing the changes in the spatial structure of the population in the municipalities with an average decrease in population, the following results were obtained: the population of Aizkraukle municipality decreased by $21.9 \%$ between 2000 and 2018 , while in $20.8 \%$ of the populated area the population increased; in Skriveri municipality these rates were $-17.3 \%$ and $8.7 \%$ respectively (Table 2).

Table 2. Population changes and changes in the spatial structure of the population in 1x1 km square grid areas between 2000 and 2018 in Aizkraukle and Skriveri municipalities (based on CSB data)

\begin{tabular}{|l|c|c|}
\hline \multicolumn{1}{|c|}{ Statistical characteristic } & $\begin{array}{c}\text { Aizkraukle } \\
\text { municipality }\end{array}$ & $\begin{array}{c}\text { Skriveri } \\
\text { municipality }\end{array}$ \\
\hline Population at the beginning of 2000 & 10414 & 4082 \\
\hline Population at the beginning of 2018 & 8130 & 3366 \\
\hline Population changes 2018/2000 (\%) & -21.93 & -17.54 \\
\hline Number of spatial squares & 100 & 102 \\
\hline Number of spatial squares without population & 47 & 33 \\
\hline Number of spatial squares with population & 53 & 69 \\
\hline $\begin{array}{l}\text { The number of spatial squares in which the population } \\
\text { increased }\end{array}$ & 11 & 6 \\
\hline $\begin{array}{l}\text { The number of spatial squares in which the population } \\
\text { decreased }\end{array}$ & 13 & 18 \\
\hline $\begin{array}{l}\text { The percentage of populated spatial squares in which the } \\
\text { population increased }\end{array}$ & 20.75 & 8.70 \\
\hline $\begin{array}{l}\text { The percentage of populated spatial squares in which the } \\
\text { population decreased }\end{array}$ & 24.53 & 26.09 \\
\hline
\end{tabular}


In Kekava, Salaspils and Stopini municipalities, most of the area is populated (i.e., almost all spatial squares in Stopini municipality). The population of these municipalities has increased in most areas. Comparing the changes in the spatial structure of the population in the municipalities with the population increase, the following results were obtained. Between 2000 and 2018 the population of Kekava municipality increased by $46.2 \%$ and the population increased in $47.3 \%$ of the populated area. In Stopini municipality these rates are $51.1 \%$ and $52.1 \%$, while in Salaspils they are $-5.3 \%$ and $45.7 \%$ respectively (Table 3 ).

Table 3. Population changes between 2000 and 2018 and changes in the spatial structure of the population in 1x1 km square grid areas between 2000 and 2018 in Kekava, Salaspils and Stopini municipalities (based on CSB data)

\begin{tabular}{|l|c|c|c|}
\hline \multicolumn{1}{|c|}{ Statistical characteristic } & $\begin{array}{c}\text { Kekava } \\
\text { municipality }\end{array}$ & $\begin{array}{c}\text { Salaspils } \\
\text { municipality }\end{array}$ & $\begin{array}{c}\text { Stopinini } \\
\text { municipality }\end{array}$ \\
\hline Population at the beginning of 2000 & 15762 & 21425 & 6942 \\
\hline Population at the beginning of 2018 & 23042 & 22555 & 10492 \\
\hline Population changes 2018/2000 (\%) & 46.18703 & 5.274212 & 51.138 \\
\hline Number of spatial squares & 270 & 122 & 49 \\
\hline $\begin{array}{l}\text { Number of spatial squares without } \\
\text { population }\end{array}$ & 103 & 30 & 1 \\
\hline $\begin{array}{l}\text { Number of spatial squares with } \\
\text { population }\end{array}$ & 167 & 92 & 48 \\
\hline $\begin{array}{l}\text { The number of spatial squares in } \\
\text { which the population increased }\end{array}$ & 79 & 13 & 6 \\
\hline $\begin{array}{l}\text { The number of spatial squares in } \\
\text { which the population decreased }\end{array}$ & 23 & 45.65 & 52.08 \\
\hline $\begin{array}{l}\text { The percentage of populated spatial } \\
\text { squares in which the population } \\
\text { increased }\end{array}$ & 47.31 & 14.13 & 12.50 \\
\hline $\begin{array}{l}\text { The percentage of populated spatial } \\
\text { squares in which the population } \\
\text { decreased }\end{array}$ & 13.77 & & 6 \\
\hline
\end{tabular}

\section{Conclusion}

Internal migration analysis at the regional level indicate that the desire to improve quality of life is the main motive behind the change of residence.

From the obtained results of the spatial structure analysis of the population in the reference territories, it could be hypothesised that the proportion of territories with population increase in Latvian municipalities (2000-2018) has a very strong and statistically significant correlation to population changes (2000-2018) in the respective municipality.

This may lead to the conclusion that the influence of other factors on the location of the territories in the spatial structure of the municipality where population growth is observed is not statistically significant. 


\section{Kopsavilkums}

Rakstā analizēti faktori, kas ietekmē un nosaka vietējo iedzīvotāju skaita pieaugumu un samazināšanos Latvijas lauku novados, pamatojoties uz iedzīvotāju skaita pārmaiṇām mikrolīmenī analizējot regulāra režğa 1x1 km tīkla pārklājumu 2000. - 2018. gadā. Iedzīvotāju telpiskās struktūras kvantitatīvā analīze tika veikta trīs etalonteritorijās. Rezultāti liecina, ka teritoriju īpatsvaram ar iedzīvotāju skaita pieaugumu Latvijas novados (2000-2018) ir statistiski nozīmīga korelācija ar iedzīvotāju skaita pārmaiṇām (2000-2018) attiecīgajā novadā. Autori tālākiem pētījumiem izvirza hipotēzi, ka citu faktoru ietekme uz teritoriju izvietojumu pašvaldības telpiskajā struktūrā, kurā tiek novērota iedzīvotāju skaita palielināšanās, varētu nebūt statistiski nozīmīga.

\section{References}

Apsite, E., Krišjāne, Z., Berzins, M. (2012). Emigration from Latvia under economic crisis conditions. International Proceedings of Economics Development and Research, 31, 134-138.

Arbidane I., Markevica L. (2016). Impact of Labour Force Migration on Latvia's Economy. Scientific Journal of Polonia University /Periodyk Naukowy Akademii Polonijnej, (18) 3, 69-78.

Bērziņš, M. (2011). Iekšzemes migrācijas reǵionālās dimensijas Latvijā. Latvijas Zinātnuu Akadēmijas Vēstis, A daḷa, Sociālās un humanitārās zinātnes, 65(3/4), 34-54.

Bērziņš, M., Eglīte, P., Krišjāne, Z., Kūle, L. (2018). Iedzīvotāju skaita dinamika, struktūra un to ietekmējošie faktori. In: Nikodemus, O., Kḷaviņs, M., Krišjāne, Z., Zelčs, V. (ed.) Latvija. Zeme, daba, tauta, valsts. Rīga: LU Akademiskais apgāds, 488-496.

Boyle P., Halfacree K., Robinson V. (1998). Exploring Contemporary Migration. Essex: Longman.

Brodzinski, Z. (2007). Spatial differentiation of Polish rural inhabitants' economic activity. Economic Science for Rural Development Conference Proceedings, 12, 152-157.

Camaioni, B., Coderoni, S., Esposti, R., Pagliacci, F. (2019). Drivers and indicators of the EU rural development expenditure mix across space: Do neighbourhoods matter? Ecological Indicators, 106 (11) 105505.

Champion, A. (2008). The changing nature of urban and rural areas in the UK and other European countries. United Nations expert group meeting on population distribution, urbanization, internal migration and development. New York: United Nations Secretariat, Department of Economic and Social Affairs.

Chomy, P., Jančak, V., Marada, M., Havličck, T. (2011). Rural Areas - Living Space: Regional Differences in the Perceptions of Representatives of Rural Municipalities in Czechia Regarding Rural Areas. Geografie. 116, 23-45.

Clark, J. R. A., Jones. A., Potter, C. A., Lobley, M. (1997). Conceptualising the evolution of the European Union's agri-environment policy: a discourse approach. Environment and Planning, 29, 18691885.

Eglīte, P., Markausa, I. M., Gņedovska, I., Ivbulis, B. (2003). Latvijas iedzīvotāju sastāvs, izvietojumu un tā pārmaiṇu izredzes XXI gadsimta 1. ceturksnī. Apcerējumi par Latvijas iedzīvotājiem, $10,139$.

Göler, D., Krišjāne, Z., Bērziņš, M. (2014). International Migration in the Periods of Transition and Crisis: the Case of Latvia. Baltic Region, 6 (2), 75-85.

Greenwood, M. J., Hunt, G. L. (2003). The early history of migration research. International Regional Science Review, 26, 3-37.

Harris, R. J., Todaro, M. (1970). Migration, Unemployment and Development: A Two-Sector Analysis. American Economic Review, 60 (1), 126-142.

Hazans, M. (2003). Determinants of inter-regional migration in the Baltic countries. ZEI Working Paper, B17.

Krisjane, Z., Apsite-Berina E., Berzins M., Grine I. (2017). Regional Topicalities in Latvia: Mobility and Immobility in the Countryside. Economic Science for Rural Development Conference Proceedings. 45, 127-133. 
Krisjane, Z., Berzins, M. (2012). Post-socialist Urban Trends: New Patterns and Motivations for Migration in the Suburban Areas of Riga. Latvia Urban Studies, 49 (2), 289-306.

Latvijas Republikas Saeima (2010). Latvijas ilgtspējīgas attīstības stratēgija līdz 2030. gadam “Latvija 2030”. Rīga

Michalek, J., Zarnekow, N. (2012). Application of the rural development index to analysis of rural regions in Poland and Slovakia. Social indicators research, 105 (1), 1-37.

Oddershede, A., Arias, A., Cancino, H., (2007). Rural development decision support using the Analytic Hierarchy Process. Mathematical and Computer Modeling, 46 (7/8), 1107-1114.

Ozoliņ̌s, J., Vēveris, A., Benga, E. (2015). The role of EU funds in diversification of rural economy in Latvia. Research for rural development 2015, 2, 154-160.

Poot, J., Wladorf, B., Wissen van, L. (2008). Migration in a Globalised World: A New Paradigm. In: Poot, J., Waldorf, B., Wissen van, L. (eds.) Migration and Human Capital. Edward Elgar: Cheltenham. 3-25.

Sjaastad, L. (1962). The relationship between migration and income in the United States. Papers of the Regional Science Association, 6, 37-64.

Smallbone, D. (2009). Fostering entrepreneurship in rural areas. In: Potter, J., Hofer, A.J. (eds.) Strengthening entrepreneurship and economic development in East Germany: lessons from local approaches (OECD report). 161-187.

Straka, J., Tuzova, M. (2016). Factors Affecting Development of Rural Areas in the Czech Republic: A Literature Review. Procedia - Social and Behavioral Sciences, 496-505.

Vēveris, A. (2014). Investment support and its impact on the economic results of rural farms of different groups. Economic Science for Rural Development, 34, 154-162.

Vēveris, A., Leimane, I., Krieviņa, A. (2007). Efficiency analysis of agricultural sector in Latvia compared to other EU countries, based on FADN data. Economic Science for Rural Development Conference Proceedings, 13, 13-19.

Yilmaz, B., Daşdemir, I., Erdoğan, A., Wietze, L. (2010). Factors Affecting Rural Development in Turkey: Bartın Case Study. Forest Policy and Economics. 239-249.

Zhitin D.V., Krisjane Z., Sechi G. (2018). The Effect of Migration on Latvia's Sex and Age Composition. Baltic Region, 10 (1), 107-129.

Zobena, A., Ijabs, I. (eds.) (2015). Jaunas pieejas sociālās attīstības mērī̌sanā: cilvēki, teritorijas, pašvaldības. Rīga, LU Akadēmiskais apgāds.

Zvidriņš P. (2006). Latvijas iedzīvotāju skaita un vecuma sastāva prognozes. Demogrāfiskāa attīstība Latvijā 21. gadsimta sākumā. Stratēǵiskā analīzes komisija. Zinātniski pētnieciskie raksti, 3, (9), 164187. 